Agr. Biol. Chem., 39 (9), 1813 1819, 1975

\title{
Isolation and Characterization of Antitumor Lipopolysaccharide from Proteus mirabilis ${ }^{\dagger}$
}

\author{
Mamoru Arai, Masaki Nakahara, Kiyoshi Hamano \\ and Hiroshi OKAZAKI \\ Fermentation Research Laboratories, Sankyo Co., Ltd., \\ No. 2-58, Hiromachi 1-chome, Shinagawa-ku, Tokyo 140, Japan
}

Received April 10, 1975

\begin{abstract}
Systematic isolation of the cell constituents of Proteus mirabilis RMS-203 was performed to find out localization of antitumor principle only in the lipopolysaccharide (LPS) layer of the cell wall fraction.

LPS with strong antitumor activity was extracted from $P$. mirabilis RMS-203 by phenolwater method followed by purification on DEAE-Sephadex A-50 column chromatography.

The main components of purified LPS were galactose, hexosamine, 2-keto-deoxy-octonic acid (KDO), myristic acid, $\beta$-hydroxymyristic acid and $\alpha, \varepsilon$-diaminopimelic acid.

The minimal effective dose of LPS against Ehrlich solid carcinoma in mice was $0.1 \sim$ $1.0 \mu \mathrm{g} /$ mouse. $\mathrm{LD}_{50}$ in mice and pyrogenicity in rabbits were $28 \mathrm{mg} / \mathrm{kg}$ and $10^{-3}-10^{-5} \mu \mathrm{g} / \mathrm{rabbit}$, respectively.
\end{abstract}

As previously reported, ${ }^{2,15}$ the living cells of Proteus mirabilis RMS-203, isolated from the pus of a woman's hepatomegalia, gave oncolytic effect on tumor-bearing mouse without any harmful influence on the host.

Isolation of LPS with antitumor activity from the cells of gram-negative bacteria has been extensively studied by many workers, especially by Shear and his colleagues ${ }^{18)}$ on Serratia marcescens. Chemical studies on LPS from Proteus mirabilis were done by Kotelko et al. ${ }^{10)}$ but not in relation to its antitumor activity. The antitumor effect of LPS from Proteus was only carried out by Mizuno et al. ${ }^{14)}$ using $P$. vulgaris as a source of LPS.

The present investigation deals with a systematic fractionation of the cells of $P$. mirabilis RMS-203 in relation to its antitumor activity. Isolation and purification of LPS, and its chemical and biological characterization are also presented.

Improvement in biological activity of LPS by mutation of the wild type as well as by

t Chemical and Biological Studies on Bacterial Lipopolysaccharide with Antitumor Activity. Part I. chemical modification will be reported in another paper.

\section{MATERIALS AND METHODS}

Organism. Proteus mirabilis RMS-203 isolated from the pus of a woman's hepatomegalia was used for isolation of the fraction with antitumor activity.

Medium and culture condition. For cultivation of $P$. mirabilis RMS-203, a 600 liter tank containing 400 liter medium was used. The medium was consisted of Polypepton (Daigo Eiyokagaku, Osaka) $1 \%$, meat extract $1 \%, \mathrm{NaCl} 0.5 \%$ and silicone $\mathrm{KS} 660.004 \%$, being adjusted to $\mathrm{pH} 7.25$ and sterilized at $120^{\circ} \mathrm{C}$ for $30 \mathrm{~min}$. The $\mathrm{pH}$ after sterilization was 7.55. The seed culture with $500 \mathrm{ml}$ of the medium in a 2 liter flask was shaken on a rotary shaker ( $200 \mathrm{rpm}$ ) for $40 \mathrm{hr}$ and added to the tank. Fermentation conditions were as follows: temperature $37^{\circ} \mathrm{C}$, aeration $200 \mathrm{liter} / \mathrm{min}$, inner pressure $0.5 \sim 1.0 \mathrm{~kg} / \mathrm{cm}^{2}$, and agitation $200 \mathrm{rpm}$. Silicone KS 66 was added appropriately for defoaming.

After cultivation for $24 \mathrm{hr}$, the cells were collected by Sharples centrifuge and washed twice with tap water. Total yield of the cells was $1.75 \mathrm{~kg}$ by wet weight. The cells were stocked in a freezer until use.

Systematic fractionation of the cells of $P$. mirabilis $R M S-203$. Systematic fractionation of the cells of $P$. mirabilis RMS-203 was done by the method of Martin and Frank. ${ }^{13}$ 
Isolation of LPS. Isolation of LPS from the strain RMS-203 was done by the phenol-water method of Westphal et al. ${ }^{23)}$ The cells $(1 \mathrm{~kg}$, wet) were extracted twice with $45 \%$ aqueous phenol at $65 \sim 68^{\circ} \mathrm{C}$ for $30 \mathrm{~min}$. The aqueous phase was separated by centrifugation $(9,000 \times g, 10 \mathrm{~min})$, and to the supernatant was added a mixture of $\mathrm{CH}_{3} \mathrm{COOK}(2 \%)$ and ethanol $(1: 2, \mathrm{v} / \mathrm{v})$. The precipitate formed was collected by centrifugation, dialyzed against tap water and distilled water successively, and lyophilized. The yield of crude LPS (P-1) was $20 \mathrm{~g}$. Further purification of LPS was done by chromatography on DEAE-Sephadex A-50. DEAESephadex A-50 equilibrated with $0.2 \mathrm{M} \mathrm{NaCl}$ in $0.01 \mathrm{M}$ phosphate buffer at $\mathrm{pH} 7.5$ was packed into the $2.5 \times$ $45 \mathrm{~cm}$ column. Crude LPS $(2 \mathrm{~g} / 200 \mathrm{ml}$ in the above buffer) was applied on the column, and LPS was eluted with the same buffer. LPS fraction (tube No. $5 \sim 41$ ) was collected and purified by rechromatography on the same type of the column.

Analytical methods. Total hexose was determined by the anthrone method of Yemm and Willis ${ }^{25 !}$ using glucose as the standard. Glucose was determined by glucose oxidase after hydrolysis of LPS by heating it in $1 \mathrm{~N} \mathrm{HCl}$ or $1.3 \mathrm{~N} \mathrm{H}_{2} \mathrm{SO}_{4}$ at $100^{\circ} \mathrm{C}$ for $4 \mathrm{hr}$ in evacuated and sealed tubes. Total hexosamine was determined by the method of Boas. ${ }^{3)}$ The quantitative analysis of glucosamine and galactosamine was done by the borate buffer method of Good and Bessman.7? Glucuronic acid was determined by the thioglycollic acid mannose- $\mathrm{H}_{2} \mathrm{SO}_{4}$ reaction described by Dishe, ${ }^{4}$ and galacturonic acid by the method of Kerr and Seraidarian $^{91}$ or of Kotelko et al. ${ }^{10}$ )

Protein was determined by the Folin-phenol reagent method of Lowry et al.,21 using crystalline bovine albumin as the standard.

Heptose was determined by the cysteine- $\mathrm{H}_{2} \mathrm{SO}_{4}$ reaction of Osborn ${ }^{16)}$ using L-glycero-D-mannoheptose as the standard.

Phosphorus was determined by the colorimetric method of Allen"1) using $\mathrm{KH}_{2} \mathrm{PO}_{4}$ as the standard.

Amino acid analysis was made by thin-layer chromatography ${ }^{17}$ and amino acid autoanalyzer, Hitachi type KLA-2.

The colorimetric reaction with thiobarbituric acid described by Weissbach and Hurwitz ${ }^{211}$ or by Osborn ${ }^{16 !}$ was employed to determine 2-keto-3-deoxy-octonic acid.

Lipid A was extracted with a mixture of $\mathrm{CHCl}_{3}$ : methanol $(2: 1)$ after $0.1 \mathrm{~N} \mathrm{HCl}$ hydrolysis or $1 \%$ acetic acid hydrolysis of LPS.22 Lipid B was extracted with a mixture of $\mathrm{CHCl}_{3}$ : methanol $(2: 1)$ from LPS without treatment with acid. Fatty acids of both ester and amide forms were determined by the method of Haskins and others. $5,8,19,20)$ Fatty acid methyl esters of LPS were prepared by the method of Yamakawa and Ueta. ${ }^{24}$ One microliter of methylated samples was injected into Shimazu Gas Chromatograph GS-1C flame-ionization unit equipped with stainless steel column $(3 \mathrm{~mm} \times 180 \mathrm{~cm})$ packed with $25 \%$ polydiethylene glycol succinate coated on Diasolid $L$. The column was maintained at $180^{\circ} \mathrm{C}$ and the injector port at $230^{\circ} \mathrm{C}$.

$L D_{50}$ determination. Lethal toxicity of the isolated preparations against mouse was determined with ddY or RFVL mice (female, about $20 \mathrm{~g}$ ) which were injected intravenously with the preparations dissolved in saline. Calculation of $\mathbf{L D}_{50}$ was made according to LitchfieldWilcoxon's method. ${ }^{11}$

Antitumor activity. Antitumor activity of the preparations from $P$. mirabilis RMS-203 was tested by observation of necrosis in tumor section or by the Pigment test.

Ehrlich ascites cell suspension $\left(2 \times 10^{6}\right.$ cells $\left./ 0.1 \mathrm{ml}\right)$ was implanted subcutaneously in an area of right armpit of ddY or RFVL mice. Samples for testing antitumor activity were injected intravenously to the mice on 7 to 9 days after transplantation, when a detectable tumor was developed. One week after administration, the mice were sacrificed, and necrosis in tumor sections was examined. For the Pigment test, the modified method of Goldacre and Sylvén ${ }^{6 !}$ was used. At $24 \mathrm{hr}$ after administration of test samples, the mice were injected intravenously with $0.3 \mathrm{ml}$ of $2 \%$ Light green SF yellowish or Pontamine sky blue 6B (Tokyo Kasei Kogyo Co., Ltd.) and sacrificed at $2 \mathrm{hr}$ after injection of the pigment. The tumor tissue of nontreated animal was stained greenish or bluish with the pigment whereas that injected with an active LPS fraction was not.

The results obtained by observation of necrosis agreed with those obtained by the Pigment test. Therefore, the antitumor test was done mainly by the Pigment test for the sake of time saving.

Pyrogenicity. Pyrogenicity was determined in rabbits by standard procedures in The United States Pharmacopeia (1970).

\section{RESULTS AND DISCUSSION}

Systematic procedure for the fractionation of the cell constituents of $P$. mirabilis RMS203 is shown in Chart 1. Similar to the results obtained by Martin and Frank ${ }^{13)}$ for the cells of Escherichia coli B, the cells of $P$. mirabilis RMS-203 was fractionated into cytoplasm and cell wall portion, and the latter was further into four main fractions, lipoprotein, LPS, protein granule and mucopoly- 


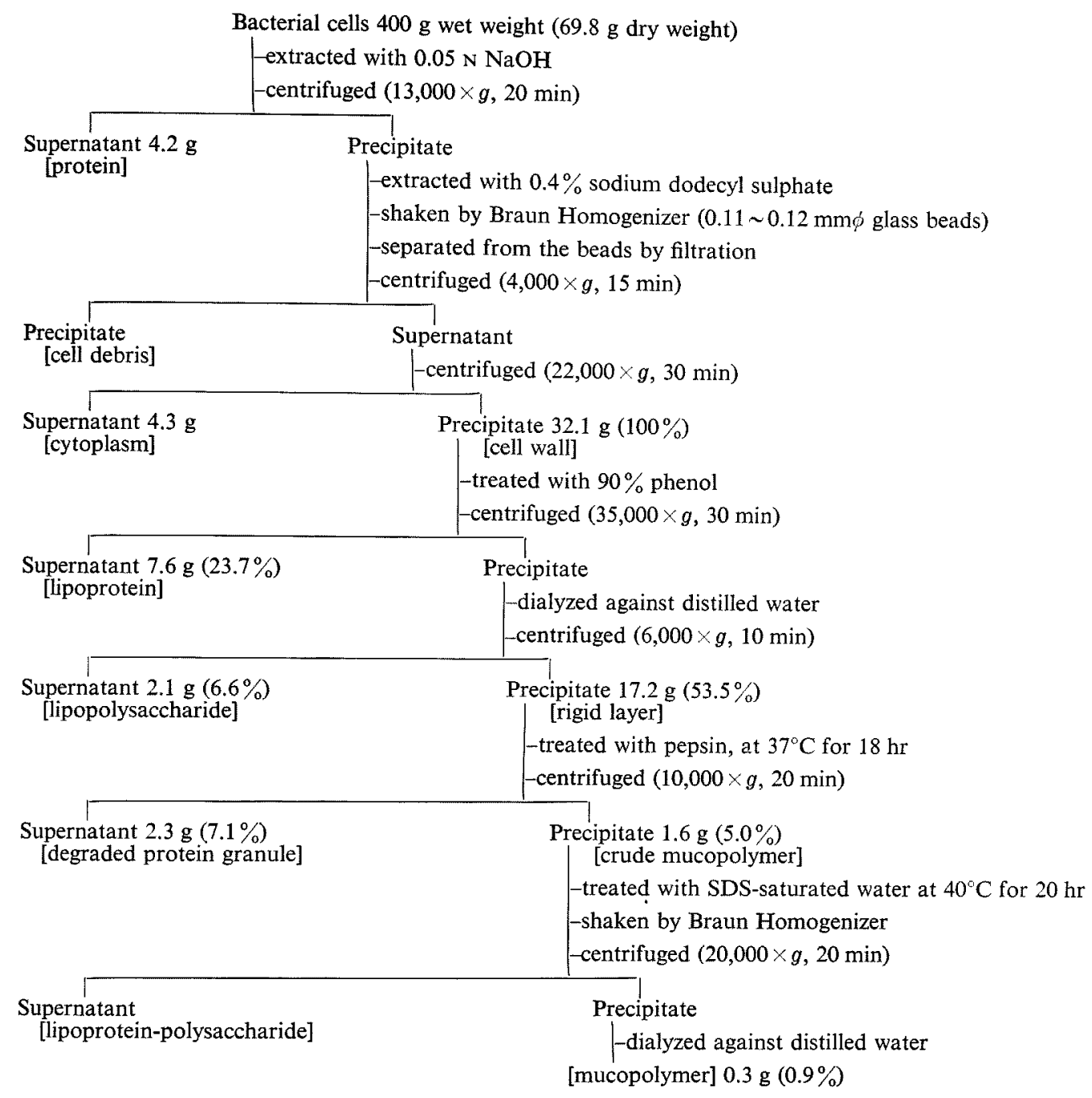

CHART 1. Systematic Isolation of Cell Wall Fractions from Proteus mirabilis RMS-203.

Table I. Chemical Composition and Biological Property of Each Cell Wall

Fraction IsOlated from Proteus mirabilis RMS-203

\begin{tabular}{lcccccc}
\hline & Hexose & Hexosamine & Heptose & Protein & Fatty acid & Antitumor activity ${ }^{a}$ \\
\hline Whole cells & $1.6 \%$ & $0.4 \%$ & $1.1 \%$ & $58.5 \%$ & $6.1 \%$ & positive \\
Cytoplasm & 2.3 & 1.5 & 0.5 & 54.7 & - & negative \\
Cell wall fraction & 0 & 0 & 0.4 & 86.5 & 12.3 & negative \\
$\quad$ Lipoprotein & 8.7 & 9.5 & 2.2 & 2.0 & 31.2 & positive \\
$\quad$ Lipopolysaccharide & 0 & 0 & 0 & 110 & - & negative \\
$\quad$ Protein granule & 4.3 & 9.0 & 1.4 & 37.3 & 22.9 & negative \\
Crude mucopolymer & 0.9 & 27.4 & 0.1 & 13.8 & 0 & negative \\
Mucopolymer & 0.9 &
\end{tabular}

a) Antitumor activity of each fraction was tested by observation of necrosis in tumor section at one week or by the Pigment test at $24 \mathrm{hr}$ after intravenous administration of the samples at a dose of $1 \sim$ $10 \mu \mathrm{g}$ per mouse. 
mer. Three layers of the cell wall, lipoprotein, LPS, and protein granule and mucopolymer contribute $62.1 \%, 20.4 \%$ and $17.5 \%$, respectively, to the total weight of the cell wall which were broadly similar to those values for $E$. coli B by Martin and Frank, $60 \%, 12 \%$ and $21 \%$.

Chemical composition and antitumor activity of each fraction are given in Table I.

Successful separation of the cell-wall layers is recognized by the result of analysis of chemical composition of each layer, such as lipoprotein layer with lipid and protein, LPS with lipid, hexose, hexosamine and heptose, protein granule with protein alone, and mucopolymer with hexosamine and protein.

The test for antitumor activity of each layer clearly indicated localization of the activity at LPS in the cell constituents.

Further purification of the antitumor principle was thus concentrated to LPS fraction of the cells of $P$. mirabilis RMS-203.

As was in most investigations in the past, LPS was prepared by the phenol-water extraction method by Westphal et al. as shown in Chart 2. Twenty grams of crude LPS (P-1) was obtained from $1 \mathrm{~kg}$ wet weight of the cells. The yield was $2 \%$. Further purification of LPS by column chromatography on DEAE-Sephadex A-50 are given in Chart 3.

Anthrone-positive LPS fraction was eluted with $0.2 \mathrm{M} \mathrm{NaCl}$ in separation from the contaminated RNA fraction eluted with higher concentration of $\mathrm{NaCl}$. The yield of purified LPS (P-3) was $6.4 \mathrm{~g}$ or $0.64 \%$ in this procedure.

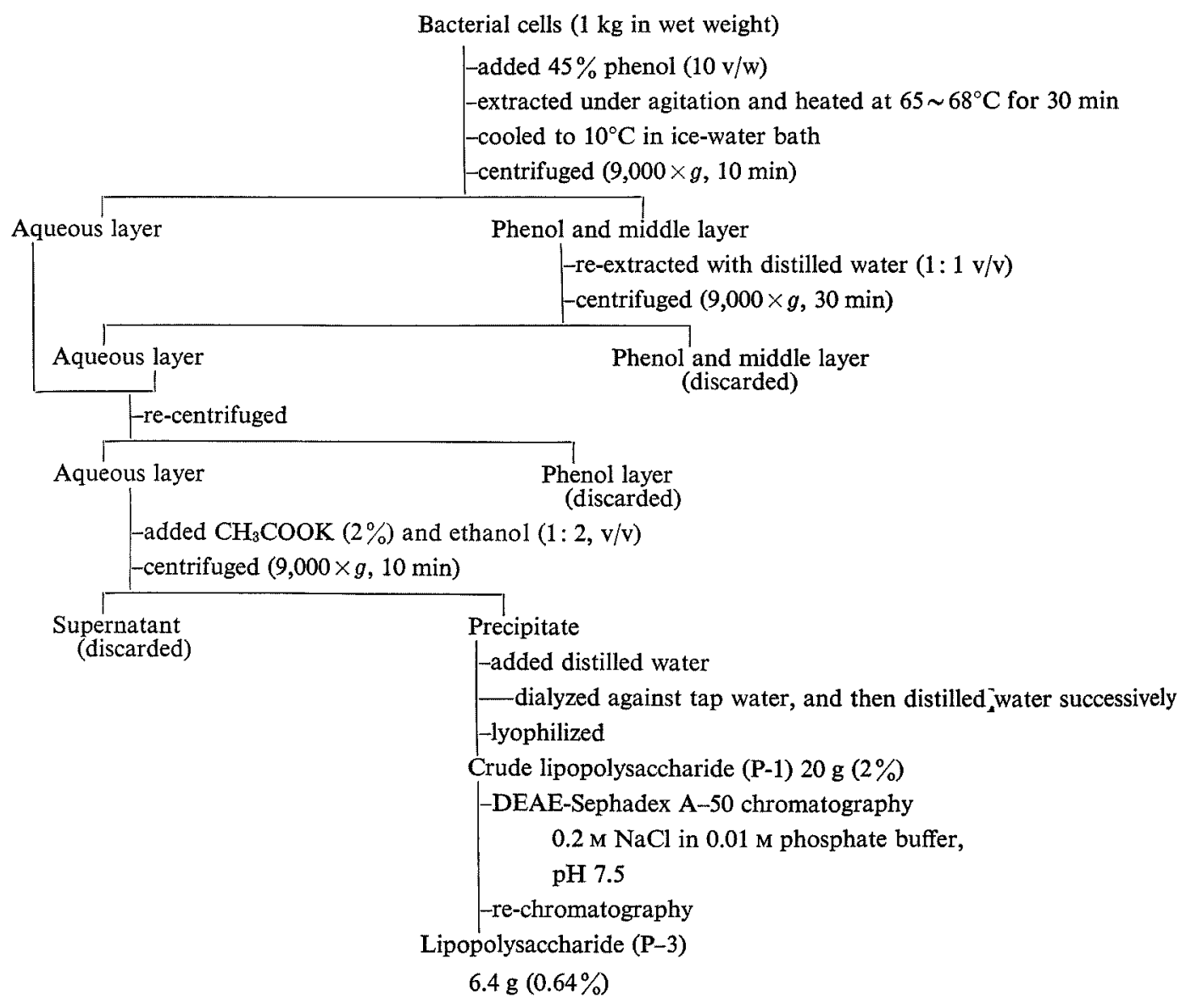

Chart 2. Extraction and Purification of LPS from Proteus mirabilis RMS-203. 


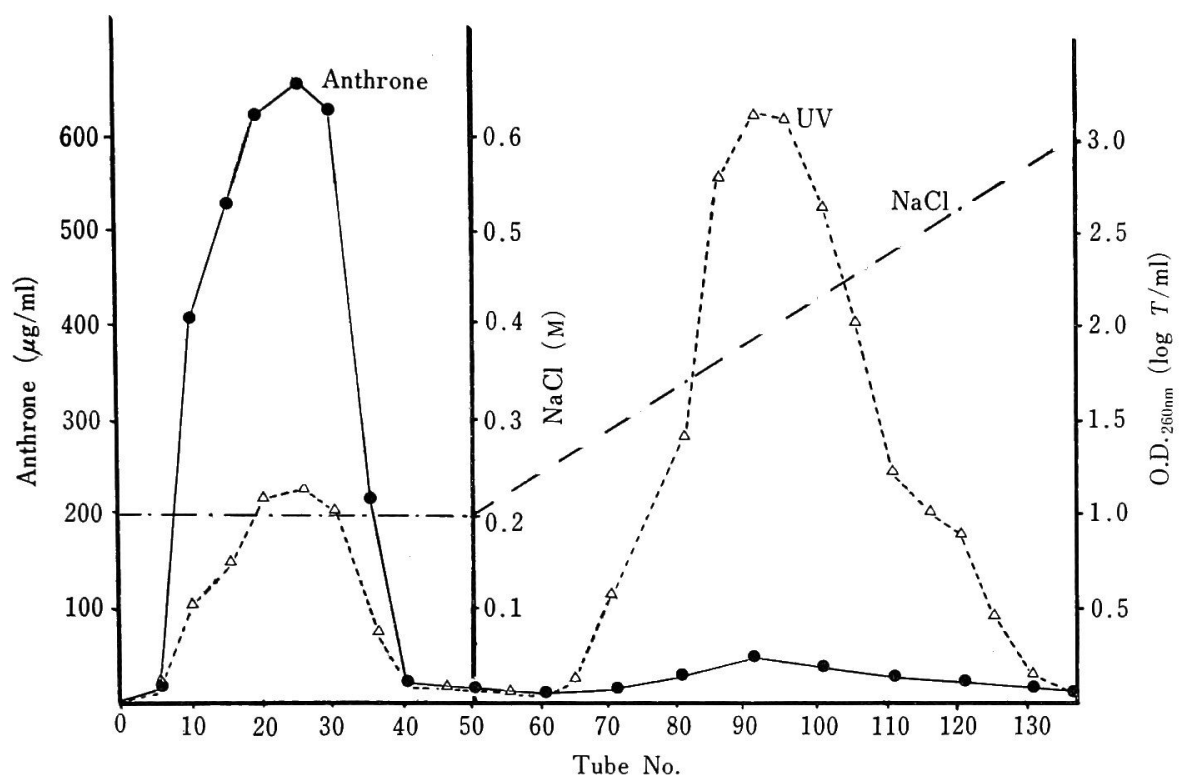

Chart 3. Purification of Crude LPS Extracted from Proteus mirabilis RMS-203 by DEAESephadex A-50 Column Chromatography.

DEAE-Sephadex A-50 was equilibrated with $0.2 \mathrm{M} \mathrm{NaCl}$ in $0.01 \mathrm{~m}$ phosphate buffer (pH 7.5) and packed into the $2.5 \times 45 \mathrm{~cm}$ column. Crude LPS $(\mathrm{P}-1,2 \mathrm{~g})$ dissolved in the same buffre $(200$ $\mathrm{ml}$ ) was applied on the column and eluted with the same buffer (10 $\mathrm{ml}$ in each tube). After elution of LPS, RNA fraction was eluted with the gradient concentration of $\mathrm{NaCl}(0.2 \rightarrow 0.6 \mathrm{M})$ in the same buffer.

LPS P-1
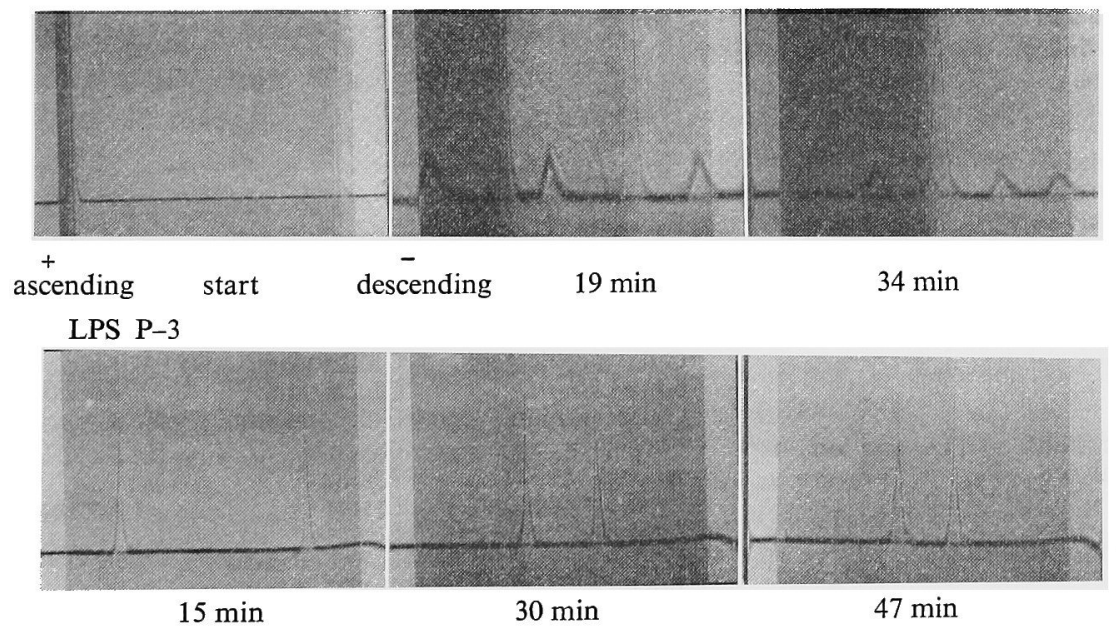

FIG 1. Tiselius Electrophoretic Patterns of LPS P-1 and P-3 Isolated from Proteus mirabilis RMS-203.

Condition: Hitachi Tiselius Electrophoretic Apparatus HTB-2A 0.1 м Veronal buffer, pH 8.6, $100 \mathrm{~V}, 7 \mathrm{~mA}$, at $14.3^{\circ} \mathrm{C}$.

The electrophoretic patterns of purified LPS and its chemical and biological properties are shown in Fig. 1 and Table II, respectively.
LPS (P-3) was found to be a single compound by means of electrophoretic analysis. Removal of RNA from LPS $(\mathrm{P}-1)$ was clearly 
Table II. Chemical Composition and Biological Properties of LPS ISOLATED FROM Proteus mirabilis RMS-203

\begin{tabular}{|c|c|c|c|}
\hline & LPS P-1 & $\begin{array}{l}\text { LPS } \\
\% \\
\end{array}$ & from $1959^{c 1}$ \\
\hline \multicolumn{4}{|l|}{ [Elementary analysis] } \\
\hline $\mathrm{C}$ & 35.9 & 43.1 & \\
\hline $\mathrm{H}$ & 6.32 & 7.36 & \\
\hline $\mathrm{N}$ & 4.20 & 3.90 & \\
\hline $\mathbf{P}$ & 3.45 & 1.73 & \\
\hline ash & - & 7.93 & \\
\hline \multicolumn{4}{|l|}{ [UV absorption at $260 \mathrm{~nm}$ ] } \\
\hline$E_{1 \% \mathrm{~m}}^{1 \%}$ & 47.3 & 7.1 & \\
\hline RNA & 16.1 & 0 & \\
\hline \multicolumn{4}{|l|}{ [Chemical composition] } \\
\hline Total hexose & 12.3 & 17.6 & 6.2 \\
\hline glucose & 2.0 & 1.9 & 6.2 \\
\hline galactose & 10.3 & 15.7 & 0 \\
\hline Heptose & 5.7 & 5.8 & 12.6 \\
\hline Total hexosamine & 9.8 & 13.9 & 13.4 \\
\hline glucosamine & 5.5 & 5.8 & 6.0 \\
\hline galactosamine & 4.3 & 8.1 & 7.4 \\
\hline 2-Keto-3-deoxy-octonic acid (KDO) & 1.4 & 1.6 & 3.8 \\
\hline Total uronic acid & - & 5.4 & 13.7 \\
\hline glucuronic acid & $(1.5)$ & $(1.4)$ & trace \\
\hline galacturonic acid & - & 4.0 & 13.7 \\
\hline Protein & 4.6 & 0.7 & \\
\hline \multicolumn{4}{|l|}{ Amino acid } \\
\hline glycine & 1.1 & 0 & \\
\hline$\alpha, s$-diaminopimelic acid (DAP) & 10.3 & 8.9 & \\
\hline \multirow{2}{*}{$\begin{aligned} \text { Lipid A } & \left(\mathrm{CH}_{3} \mathrm{COOH}\right) \\
(\mathrm{HCl}) & \end{aligned}$} & - & 33.3 & \\
\hline & 26.9 & 16.6 & \\
\hline Lipid B & 2.7 & 1.7 & \\
\hline Total fatty acid (GLC) & 7.6 & 7.4 & \\
\hline$\left(\mathrm{NH}_{2} \mathrm{OH}\right)$ & 7.6 & 7.3 & \\
\hline ester-linked & 4.9 & 6.2 & \\
\hline amide-linked & 2.7 & 1.1 & \\
\hline myristate & 3.8 & 3.6 & \\
\hline 15 anteiso & 0.2 & 0.2 & \\
\hline palmitate & 0.6 & 0.5 & \\
\hline palmitoleate & 0.2 & 0.1 & \\
\hline$\beta-\mathrm{OH}$ myristate & 2.6 & 2.8 & \\
\hline \multirow[t]{6}{*}{ Sugars detected by PPC, TLC and GLC } & Ribose & & \\
\hline & Glucose & Glucose & Glucose \\
\hline & $\begin{array}{l}\text { Galactose } \\
\text { Heptose }\end{array}$ & $\begin{array}{l}\text { Galactose } \\
\text { Heptose }\end{array}$ & Heptose \\
\hline & $\mathrm{KDO}$ & $\mathrm{KDO}$ & KDO \\
\hline & Galacturonic acid & Galacturonic acid & Galacturonic acid \\
\hline & $\begin{array}{l}\text { Glucosamine } \\
\text { Galactosamine }\end{array}$ & $\begin{array}{l}\text { Glucosamine } \\
\text { Galactosamine }\end{array}$ & $\begin{array}{l}\text { Glucosamine } \\
\text { Galactosamine }\end{array}$ \\
\hline \multirow{7}{*}{$\begin{array}{l}\text { Amino acids found on TLC and amino } \\
\text { acid autoanalyzer }\end{array}$} & Glycine & Glycine & \\
\hline & Alanine & Alanine & \\
\hline & Lysine & Lysine & Lysine \\
\hline & Leucine & Leucine & \\
\hline & $\begin{array}{l}\text { Glutamic acid } \\
\text { DAP }\end{array}$ & Glutamic acid & \\
\hline & (Aspartic acid) & (Aspartic acid) & \\
\hline & \multicolumn{3}{|c|}{ [Biological properties] } \\
\hline \multirow{3}{*}{$\begin{array}{l}\text { Antitumor activity } \mu \mathrm{g} / \text { mouth } \\
\text { Toxicity } \mathrm{LD}_{50} \text { (mouse, IV) } \mathrm{mg} / \mathrm{kg} \\
\text { Pyrogenicity } \mu \mathrm{g} / \mathrm{rabbit}\end{array}$} & $0.1 \sim 1.0$ & $0.1 \sim 1.0$ & \\
\hline & 48 & 30 & \\
\hline & $10^{-3} \sim 10^{-7}$ & $10^{-9}$ & \\
\hline \multicolumn{4}{|c|}{$\begin{array}{l}\text { a) LPS P-1: Crude LPS isolated by phenol-water method followed by precipitation with } \mathrm{CH}_{3} \mathrm{COOK} \\
\text { and ethanol as described in Chart } 2 \text {. }\end{array}$} \\
\hline \multicolumn{4}{|c|}{$\begin{array}{l}\text { b) LP P-3: Purified LPS obtained by DEAE-Sephadex chromatography of LPS P-1 as described } \\
\text { in Chart } 2 \text {. }\end{array}$} \\
\hline \multicolumn{4}{|c|}{$\begin{array}{l}\text { LPS from 1959: LPS isolated from Proteus mirabilis 1959. The data cited from the paper by } \\
\text { Kotelko et al. }{ }^{10} \text {. }\end{array}$} \\
\hline
\end{tabular}


demonstrated by loss of UV-absorption at $260 \mathrm{~nm}$ in LPS (P-3).

Galactose rather than glucose is a major hexose constituent of the LPS of $P$. mirabilis RMS-203 in contrast to the result obtained by Kotelko et al. ${ }^{10)}$ of $P$. mirabilis strain 1959 in which only glucose was detected as a hexose constituent of LPS.

The differences between above two strains of $P$. mirabilis were also demonstrated in the amounts of heptose and galacturonic acid found in the constituents of their LPS. A part of heptose, KDO and galacturonic acid constituents of the strain 1959 might be replaced by galactose in the strain RMS- 203 . Hexosamine content was, however, in good agreement with both strains suggesting the resemblance of their lipid A fraction composed of hexosamine polymer.

Most of fatty-acid constituents in LPS is ester-linked one mainly composed of myristic and $\beta-\mathrm{OH}$ myristic acids.

Lysine is a sole amino acid detected in LPS of strain 1959, but the presence of some other amino acids is also detected in the case of strain RMS-203.

Antitumor effect of LPS from $P$. mirabilis RMS-203 on the solid-type of Ehrlich carcinoma appeared after single intravenous injection even at a concentration as low as 0.1 to $1 \mathrm{mg} / \mathrm{kg}$ ( 2 to $20 \mu \mathrm{g} /$ mouse, once). A similar anti-tumor effect but with higher concentration $(100 \mu \mathrm{g} /$ mouse, 3 times $)$ was reported by Mizuno et al. ${ }^{14)}$ using LPS of $P$. vulgaris OX 19 origin. A comparable degree of toxicity was noted for LPS from $P$. mirabilis RMS-203 with that for $P$. vulgaris $\mathrm{OX}-19\left(\mathrm{LD}_{50}=80 \mathrm{mg} /\right.$ $\mathrm{kg}$, mouse, ip).

In conclusion, the existence of toxicity and pyrogenicity in the present LPS prevents its therapeutic use in spite of its significant antitumor activity.

Further studies in an attempt to decrease these unfavorable features of LPS by microbiological and chemical modification will be reported in the next paper.

Acknowledgement. We are indebted to Dr. Toyojiro Murata for his supply of Proteus mirabilis RMS203 and for useful discussions throughout this work.

\section{REFERENCES}

1) R. J. L. Allen, Biochem. J., 34, 858 (1960).

2) M. Arakawa, K. Sugiura, H. C. Reilly and C. C. Stock, Gann, 59, 117 (1968).

3) N. Boas, J. Biol. Chem., 204, 553 (1953).

4) Z. Dishe, ibid., 171, 725 (1947).

5) R. F. Godden, N. H. LeBlanc and C. M. Wright, Analyt. Chem., 27, 1251 (1955).

6) R. J. Goldacre and B. Sylvén Brit. J. Cancer, 16, 306 (1962).

7) T. A. Good and S. P. Bessman, Analyt. Biochem., 9, 253 (1964).

8) W. T. Haskins, Analyt. Chem., 33, 1445 (1961).

9) S. E. Kerr and K. Seraidarian, J. Biol. Chem., 159, 211 (1945).

10) K. Kotelko, O. Lüderitz and O. Westphal, Biochem. Z., 343, 227 (1965).

11) J. T. Litchfield and F. Wilcoxon, J. Pharmacol. Exp. Therap., 96, 99 (1949).

12) O. H. Lowry, N. J. Rosebrough, A. L. Farr and R. J. Randall, J. Biol. Chem., 193, 265 (1951).

13) H. H. Martin and H. Frank, Z. Naturforsah., 17b, 190 (1962).

14) D. Mizuno, O. Yoshioka, M. Akamatsu and T. Kataoka, Cancer Res., 28, 1531 (1968).

15) T. Murata, M. Arakawa, Y. Sugiya, Y. Inazu, Z. Hattori, Y. Suzuki, H. Minakami, M. Nakahara and H. Okazaki, Life Sci., 4, 1055 (1965).

16) M. J. Osborn, Proc. Nat. Acad. Sci., 50, 499 (1963).

17) G. Pataki, J. Chromatog., 17, 580 (1965).

18) M. J. Shear, F. C. Turner, A. Perrault and T. Shovelton, J. Nat. Cancer Inst., 4, 81 (1943).

19) F. Synder and N. Stephens, Biochem. Biophys. Acta, 34, 244 (1959).

20) H. Tauber, Federation Proc., 19, 245 (1960).

21) A. Weissbach and J. Hurwitz, J. Biol. Chem., 234, 705 (1959).

22) $O$. Westphal and $O$. Lüderitz, Angew. Chem., 66, 407 (1954).

23) $O$. Westphal, O. Lüderitz and F. Biester, $Z$. Naturforsch., 7b, 148 (1952),

24) T. Yamakawa and N. Ueta, Japan J. Exp. Med., 34, 361 (1964).

25) E. W. Yemm and A. J. Willis, Biochem. J., 57, 508 (1954). 